\title{
Decision-Making Procedures and Their Relation to Knowledge Management and Quality Management
}

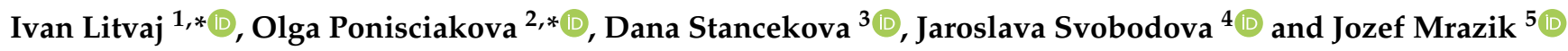 \\ 1 Department of Power Systems and Electric Drives, Faculty of Electrical Engineering and Information \\ Technology, University of Zilina, 01026 Zilina, Slovakia \\ 2 Department of Economics, Faculty of Operation and Economics of Transport and Communications, \\ University of Zilina, 01026 Zilina, Slovakia \\ 3 Department of Machining and Production Technologies, The Faculty of Mechanical Engineering, \\ University of Zilina, 01026 Zilina, Slovakia; dana.stancekova@stroj.uniza.sk \\ 4 Department of Technical Sciences, Faculty of Mechanical Engineering, University of J. E. Purkyne, \\ 40001 Usti nad Labem, Czech Republic; jaroslava.svobodova@ujep.cz \\ 5 Department of Machining and Production Technologies, Faculty of Electrical Engineering and Information \\ Technology, University of Zilina, 01026 Zilina, Slovakia; jozef.mrazik@stroj.uniza.sk \\ * Correspondence: ivan.litvaj@feit.uniza.sk (I.L.); olga.ponisciakova@fpedas.uniza.sk (O.P.); \\ Tel.: +421-41-513-2168 (I.L.); +421-41-513-3216 (O.P.)
}

Citation: Litvaj, I.; Ponisciakova, O.; Stancekova, D.; Svobodova, J.; Mrazik, J. Decision-Making Procedures and Their Relation to Knowledge Management and Quality Management. Sustainability 2022, 14, 572. https://doi.org/10.3390/ su14010572

Academic Editor: Meir Russ

Received: 25 October 2021

Accepted: 24 December 2021

Published: 5 January 2022

Publisher's Note: MDPI stays neutral with regard to jurisdictional claims in published maps and institutional affiliations.

Copyright: (C) 2022 by the authors. Licensee MDPI, Basel, Switzerland. This article is an open access article distributed under the terms and conditions of the Creative Commons Attribution (CC BY) license (https:// creativecommons.org/licenses/by/ $4.0 /)$.

\begin{abstract}
The environment in which managers currently operate is dynamic and turbulent. This fact affects the great complexity and dynamism of changes. Thus, decision-making becomes more complex in the context of sustainability. Decisive decision-making is becoming rare, and the challenge of globalization is increasing. Under its influence, decision-making is no longer deterministic. Decisionmaking processes prevail in conditions of uncertainty. In this context, there is a very intense need to be acquainted with progressive tools to support decision-making and management and to apply the acquired knowledge in practice. This paper focuses on three related areas. We are talking about knowledge management in connection with the most important contributing element-decisionmaking with quality management. We deal with the characteristics of the individual areas, defining their mutual relationship on a systemic basis. The paper also points to the necessary connection between theory and practice. More specifically, it points to the practical applications of management to decision-making as a managerial function and, at the same time, related to decision-making in quality management. Subsequently, we define the links to knowledge management with an emphasis on the use of procedures, methods, and knowledge in the decision-making process, which we use in theory and practice in quality management.
\end{abstract}

Keywords: management; decision; decision-making procedures; knowledge management; quality management

\section{Introduction}

The current market economy is characterized by turbulent development and uncertainty and the number of changes is growing. Entrepreneurs are expected to increase economic development and take responsibility for their activities, thus ensuring the spread of economic development [1]. After examining studies in the literature, the effects of entrepreneurship on regional development will be positively supported $[2,3]$. According to researchers, entrepreneurs may face many obstacles, such as a lack of financial assistance, a lack of information on business matters, high taxes, and inflation [4,5]. In particular, the increasing quality of entrepreneurship education plays an important role in the growth of entrepreneurs [6].

These turbulent developments often lead to new crises of a global nature. Economic operators must take on new challenges, look for ways to stay in the market, and develop, 
which requires the application of sustainability principles. Sustainability is a way of accessing all planning and decision-making processes aimed at achieving the sustainable development of society while protecting the environment. In this context, the causal relationship between the application of knowledge management and the creation of a sustainable competitive advantage resonates. It is built on the process of implementing knowledge management, gaining innovation potential, and creating a sustainable competitive advantage. Innovation is a product of the implementation process of knowledge management and represents a significant determinant of the competitiveness of economic entities in the global market. For example, innovation can neutralize $\mathrm{CO}_{2}$ emissions at all stages of a product's production and use. We will achieve this goal by applying innovations in which we use the knowledge of employees as the most valuable capital that the company has. The effective use of knowledge has its merits; it contributes to sustainable development and sustainability, as such, in the global economy. Knowledge management is, thus, a key determinant of a company's competitiveness. We therefore want to emphasize the need to integrate sustainable development into all decision-making processes at all levels of corporate and economic management.

To ensure the desired development in this context, it is necessary to link the functioning knowledge management necessary for correct managerial decisions, which contributes to increasing the level of quality management. For a better understanding, we take a closer look at this concept in the following section, as the success of economic entities in the market requires sustainable development. Otherwise, they lose their positions, and, today, these entities often lose in competition.

In this paper, we focus on the important functional interconnection of knowledge management for the needs of effective decision-making of economic entities in all their processes.

In [7], the authors also confirmed the importance of knowledge. They argued that, given the growing competitive environment, recognizing the strategic value of knowledge as an important resource for maintaining a competitive advantage and improving organizational performance. The relationship between modern management and knowledge management is explained in the literature as follows: Organizational development in response to change is part of the transition from an industrial society to a knowledge-based society whose economic basis is the creation and exchange of intangible goods and services. The people of the knowledge society are the main players in the knowledge society who can create and use new knowledge effectively, intentionally, and continuously. The response to these requirements is the emergence of a new discipline-knowledge management, which seeks to develop a systematic way of identifying, acquiring, maintaining, and using intellectual capital [8]. Conscious knowledge management can significantly improve the organization's work and, thus, its overall performance. Knowledge is stored in people's minds, not in information systems. If we want to work with knowledge, we must work with people. Knowledge: Knowledge $=$ information $+x, x=$ previous knowledge, skills and experience, mental models, relationships, the values and principles according to which we live, and what we believe in. Knowledge is related to human activity and emotions. Knowledge management is a deliberate activity designed to ensure that people have the right knowledge at the right time. In [9], the authors also confirmed this idea. They claimed that the basic goal of knowledge management is the appropriate shaping of knowledge resources in the organization and ensuring its smooth flow in the individual functional areas of the enterprise. Organizations that know how to manage knowledge and manage it consciously achieve success in a short time. The rationale for knowledge management functionality needs to be emphasized as an added value in achieving sustainable development. This requirement is based on the UN Commission's definition: sustainable development is development that meets the needs of current generations without compromising the needs of future generations and without doing so at the expense of other nations. In Slovakia, sustainability requirements are taken into account on the basis of the National Strategy for Sustainable Development. It is an extensive strategy focused on cultural, social, environmental, and institutional conditions, each of which requires the implementation 
of knowledge and, thus, functional knowledge management. There is no need to spend a lot of money on knowledge management; Knowledge management is not based on IT systems, such as data and information management. It is based on conscious work with the bearers and owners of knowledge-people [10]. In [11], the author concluded that these words bring us a new paradigm - the only advantage in competition will be people who have the knowledge and the ability to use it effectively in practice. This is the basis for knowledge management-a trend in management that brings social change. The importance of knowledge management lies in the effort to understand the theoretical level and to help in the practical creation of the social and technical conditions that will help and motivate the acquisition, capture, sharing, and use of knowledge in the organization [12] Good knowledge is the basis for good decision-making. In [13], the authors argued that the on-demand availability of consolidated information is a critical success factor to performing decision-making activities. Similarly, in [14], the authors stated that knowledge management and decision-making strategies are crucial factors for organizations. In the context of decision-making and the decision-making process, some important facts need to be emphasized. The decision-making process always arises when there are several solutions for the output, but at least two alternatives. Managers at all levels in the company face many challenges in carrying out their profession, which require them to take a stand and decide. These problems are related, not only to the internal environment of the companies where managers work, but also to the turbulent external environment. Decision-making is linked to the great variability of relevant changes. In [15], the authors declared that, firstly, the large number of decision-makers and their diverse backgrounds may lead to uncertainty and/or inconsistency and, so, it makes it difficult to assess the quality of the information provided, as well as to merge this information. Secondly, they declared that it is desirable, or even indispensable, depending on the situation, to obtain a solution accepted by most of the decision-makers, or at least to assess the existing level of agreement. Decision-making is one of the most important management activities performed in companies. Decision-making is an essential and irreplaceable part of management. The quality of management depends on the quality of its decision-making. Management decision-making is a special type of decision-making. Its importance in the company is manifested mainly in the fact that its quality and the results of these processes, especially the strategic decision-making processes, have a fundamental impact on the efficiency and future prosperity of the company [16]. Decision-making analysis generally assumes that the decision-maker faces problems in deciding, where the decision-maker has to choose one of a number of options. In principle, the decision-maker must have at least some knowledge of the phenomenon; otherwise, he will not be able to make reasonable and justifiable decisions [17-20]. Decision-making can be defined as the process of identifying and selecting alternatives/variants based on the values and preferences of the decision-maker. We can now see how decision-making in organizations changes from instinctive "art" to decision-making driven by data, facts, and information [21-23] using various methods, analysis, and computer technology. In our paper, we focus on several areas of management: decision-making, decision-making processes, and knowledge management. We gradually describe, in detail: decision-making, decision-making processes in theory and practice and their relationship, and the relationship with knowledge management. We also specifically focus on decision-making in the field of quality management. The goal of quality management in organizations is to satisfy the requirements of customers and other stakeholders. We have selected some very important and concise quality characteristics.

\subsection{Theoretical Background}

Common Meanings of Quality

1. Quality is fitness for use:

- Quality means the product or service does what it is intended to do.

- Poor quality of a product or service cost users if it does not do what it is supposed to do. 
2. Quality is meeting customer expectations:

- Quality is satisfying the customer.

- $\quad$ The customer defines quality.

- The customer perceives the quality of a product or service.

3. Quality is exceeding customer expectations.

- Quality is the extent to which the customers or users believe the product or service surpasses their needs and expectations.

- Quality is delighting the customer.

- Quality is superiority to competitors. Quality is how a company's products and services compare to those of competitors or how they compare to those offered by the company in the past [24].

In [25], the authors claimed that quality means conformance to requirements. In [26,27], the authors pointed out that quality is the decisive factor for the stable economic production efficiency of businesses. Companies with modern systems of quality management show better long-term results than companies traditionally oriented to quality through technical control. Quality improvement is an integral part of quality management. Quality improvement management (product quality and process quality) is an essential part of business management. In this context, we can cite, for example, B. Gatesa: Your most unhappy customers are your greatest source of learning.

\subsubsection{Decision-Making in Management and the Decision-Making Process}

Management decision-making is a very important process that consists of precisely defined systematic steps and activities that lead from the formulation and definition of a problem that needs to be solved in the company to the goal, and the goal is to select the optimal solution for the problem. The decision-making process is, therefore, one of the most important activities that managers perform in companies. It can be realized intuitively and is based on the empirical experience of the decision-maker, as is often the case with deterministic decision problems. With the increasing dynamics of changes in the surrounding environment of the company, together with the complexity, the manager is increasingly obliged to decide in conditions of uncertainty, where he not only does not know what the state of the environment will be, he also cannot detect the probability of occurrence. Considering this trend, the discipline of decision theory is an irreplaceable source of guidance.

1.1.2. Decision-Making and the Requirements for the Decision-Making Process, at the Present Time

Managers are now under more pressure than they were in the past, for example, in the last century. This is due to the changing conditions for businesses in the global market. They are exposed to environmental pressure; this pressure is caused by constantly changing external factors affecting all businesses and organizations. Globalization and technologies and their rapid development are the main megatrends of civilization. Presently, competition includes constant market changes while the frequency of these changes is steadily increasing, accelerating product and technology innovations, modern management systems, innovations in business management, etc. In such a complex and challenging environment, managers have to make decisions. We can say that it in such an environment that the demands and pressures on managers to make the right decisions are naturally increasing. The description of the activities in the decision-making process is shown in Figure 1: 


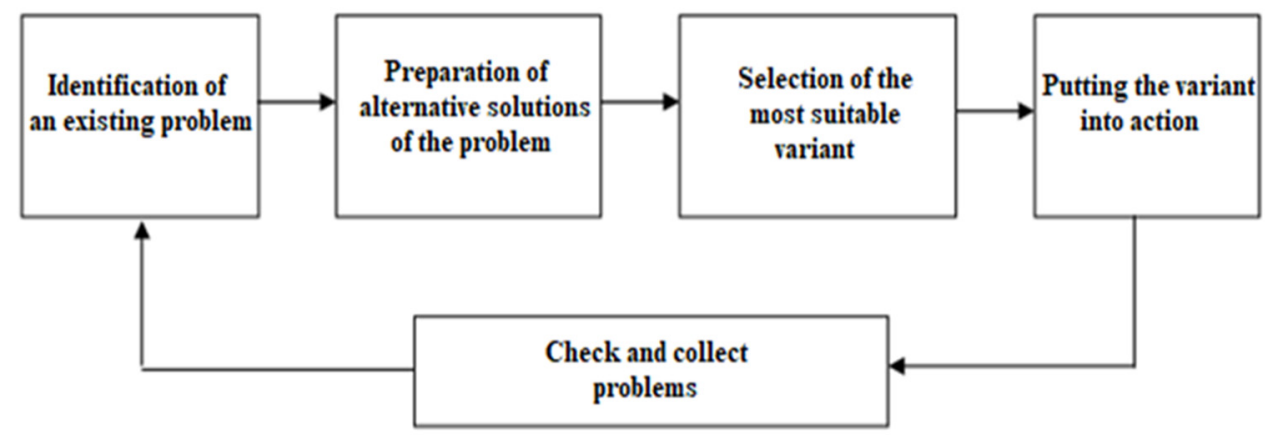

Figure 1. Decision-making process.

\subsubsection{Manager as a Decision-Maker}

Defining a manager as a person is not a simple matter because managers work in a variety of positions and levels of management. There are many definitions for the term manager, and we have chosen the following:

- A manager can be defined as a person whose primary activities are the managerial functions by which he acts on objects of management. A manager is a person who plans, organizes, manages, and controls human, financial, and information resources [28].

- The manager is primarily a profession - the manager, through managerial functions, directs the activities of the organizational unit (departments, teams) to achieve the set goals [29]. A manager can be defined as an area manager who applies his vision, has a strategic perspective, works with ideas, and looks ahead [30].

- Managers are responsible for delivering results through the dedicated efforts of other people, individually, in groups, or organizations [31].

Various factors such as time, human potential, goals, and others influence the manager's decision in the organization. For managerial decision-making, it is necessary to establish three ways-rationally, intuitively, and spontaneously.

\subsubsection{Types of Decision-Making in Management}

Decision making, therefore, requires the competence of the manager as a decisionmaker. Simply wanting to make decisions does not yet entitle the person to participate in the decision-making process. Even where the decision is legally enshrined, there is no guarantee of a particularly high-quality decision. For anyone to make decisions, they must first ensure that they have the necessary competences to do so. In management, we know three types of decision-making: rational, spontaneous, and intuitive.

\subsubsection{Rational Decision-Making}

All decisions made by managers must be rational. The element of rationality in the manager's decision-making process is an essential prerequisite for the performance of the managerial function. The elements of rationality include:

- Consistency. The steps taken in the decision-making process are oriented towards the interests of the organization and are related to the achievement of the objectives of the particular organization.

- Objectivity and logic. Decisions are carried out in the interests of the best objective of the organization. The objectives of the organization are prioritized, and personal interests are not preferred.

- Logical. The logical organization of all objectives in the organization, including their specificity, measurability, and others [32]. 


\section{Materials and Methods}

In order to approach the subject matter, it was necessary to base the information and analyses on the relevant literature and other available sources of knowledge. The acquired knowledge regarding development, formation, and basic characteristics was subsequently synthesized and used in practical application. The required output was realized using the methods of analysis, synthesis, and abstraction using a logical-deductive approach.

\section{Results}

\subsection{A New One Deciding}

Management theory has long been concerned with the definition of management, and the result is a wide range of definitions that always signal the vision of their authors. We found a definition based on the classical school of management. The definition of management based on the behavioral concept is not new, and the new school of management combines management with a specific work, which is very narrowly limited. In this category, we also found a definition of management that represents management as a decision-making process, and there are even opinions that management can be identified with decision-making. In practical terms, managerial work is a set of all activities that are defined by individual management schools, and it is very difficult to define it clearly. Of course, the manager must primarily make decisions but must also organize, plan, control, pay attention to human resources, etc. Perhaps the most intertwining of the management processes is the decision-making and information process because, without high-quality information, no decisions can be made in the first place, and consequently, planning, organizing, controlling, and managing people cannot be completed. Based on this philosophy, the following paper provides an insight into the trends in the development of decision-making processes, as they are formed in accordance with the dynamics and complexity of the environment in which executives operate, as well as in line with the growing pressure from public authorities and customers on environmental and social issues. It is a reality that economic operators will take a greater responsibility to guarantee sustainable development. This requires managers to be able to quantify the relationships of the economic, business, social, and environmental aspects at different time horizons and to link their knowledge base with strategy and results so that they can consider the trade-offs between the different alternatives. Managers are currently facing enormous demands as decision-making situations are becoming increasingly complex, and the business environment is becoming increasingly unstable. Few companies operate in a stable or even relatively stable environment, and in addition to intuition and knowledge, the application of different decision-making models, in a wide range of decision-making situations, also gains importance. A prerequisite for their use is the perception of a business as a system, which means the ability to analyze the business into elementary components and to know the interrelationship between them. However, in the very volatile present day, in which there is some degree of predictability and order, the classical systemic approach is no longer sufficient, and modelling decision-making requires the formulation of a new theory based on the science of complexity. This is because the degree of certainty decreases, and some predictability is conditional on some simplification that is appropriate for normal circumstances but loses its applicability in the first situation that deviates from the standard. The new theory, which seeks to assist managers in managing stressful situations, is called the Cynefin framework and is based on the principle of complexity [33]. The benefit is the ability to enable managers to see things and situations in their complexity and, at the same time, define the prevailing operational context in order to use an effective and adequate way of making decisions in a variety of situations. Cynefin is based on the existence of a complex system that has the following characteristics:

- Includes large numbers of interconnected elements.

- Their interaction is non-linear and small changes can cause disproportionately significant consequences.

- A system is a dynamic unit that is larger than the sum of its parts. 
- It is not possible to determine the solution; it is rather due to circumstances.

- It is very often referred to as emerging.

- The system has its history, and its past is integrated with the present.

- Elements evolve with the environment and this evolution is irreversible.

- Although a complex system may look predictable in retrospect, this view does not allow things to be predicted because the internal conditions and the system are constantly changing.

- In contrast to well-arranged systems in which the system constrains the components to some extent, in a complex system the constituents and the system limit each other, especially over time. This means that we cannot predict what will happen.

The complex systems were dominated for a long time by a view that was based on simple rules that apply in nature in general, but it is presently being recognized that human systems are very different from other natural systems and therefore cannot be modelled in the same way. The human intellect and the incalculable must be taken into account. People are different from animals because:

- They have multiple identities and freely switch between them.

- They make decisions based on past success and failure patterns more often than logically defined rules.

- They can, under certain conditions, purposefully change the systems in which they operate and thus bring them into equilibrium to achieve their intended objectives.

If management is in an environment that exhibits the characteristics of a complex system, it must change its management style, method, and tools, otherwise the management activity will not have the desired effect. The research of complex systems and their behavior based on the above characteristics has resulted in several effective tools that management should not only know but also be able to use in such a system. In more complex systems than in any other area, more interactive communication is necessary. For example, large-scale methods-LGM methods, which make room for new ideas and implement comprehensive decisions and strategies, are an effective approach to opening a democratic and open debate. People in such groups may discuss problem-solving more openly, but more importantly, they do not need to look for "best practices" outside the company but discuss what already exists and works within the organization.

\subsection{Barriers}

This instrument can be characterized as defining the barriers that, when identified, correct people's behavior. An advantage is also the self-regulating ability of such a limited system.

\subsection{Attractors}

Attractors are phenomena that arise when minor stimuli or situations leave a certain intense feeling in people when they resonate. As the strength of the attractor increases, structure and coherence are created, which has a positive impact.

\subsection{Incanting to Disconnection and Diversity}

Disagreement and formal discussion are a very valuable tool in an environment of particularly complex contexts. It is the work of parallel teams; we call the discussion "ritual opposition". The participants of the discussion work independently on the same problem in the large group environment-LGM. Each team appoints a spokesperson to move to the next table to present the conclusions of the first team. The other group hears them and then "elaborates" while the speaker is silent. After a discussion, he goes to the next table and is replaced by a representative for another team. In this way, all ideas are analyzed from all sides in one session, and people learn not only to listen carefully but also to express themselves openly and not to criticize personally. 


\subsection{Preparation of East Conditions and Monitoring Development}

In a complex context, results are always unpredictable, and therefore, managers must focus on creating an environment from which a result can emerge instead of striving to achieve predetermined results. As mentioned above, Cynefin is mainly used for managerial work that is carried out in an irrational and unpredictable world. Such a world raises many problems that classify the Cynefin framework into the five most important contexts. The criterion of the breakdown is the cause-effect relationship. These are the following contexts:

- Difficult.

- Simple.

- Complex.

- Chaotic.

- Breakdown.

A simple context, coupled with a complex chaotic context and a complex context, requires that people first diagnose the situation and then act appropriately; the lastdisruption-comes when it is unclear which of the four prevails. A common feature of all contexts is that they require a specific style of management and decision-making, all of which carry different risks. It is characterized by stability and clear cause-effect relationships that are recognizable at first sight. It is an area of "known knows." In this area, decisions are unchallengeable, because all the parties agree. The simple context is typical of areas that are subject to very little change (order processing and processing). If the simple context is evaluated, it requires straightforward management and monitoring. In this case, executives evaluate intuitively, as well as categorize and respond. This means that they will sort out the obtained facts and then react according to established practice. However, if there is a problem, the executive can usually:

- Identify (the repayment received is lower than it should have been).

- Categorize (check the documentation and find out how to proceed in future instalments).

- Respond appropriately (will not accept payment).

The characteristics of a simple context also include the availability of all the necessary information for both managers and executives, providing an atmosphere of stability. The "management and control" style is best suited to this because the instructions are clear, decisions can be easily delegated, and the functions are automated. The problem of a simple context is the possibility of an incorrect evaluation of some issues due to too much simplification. This risk is particularly exposed to managers who insist on the so-called condensed information regardless of the complexity of the situation. Another problem may be the conservative thinking of managers, which is, in other words, the tendency to practice rehearsal, which is basically a conditional reflex in which people, because of their previous experience, training, and especially success, are unable, and perhaps unwilling, to see new solutions. It may also happen that if everything develops without any problems for some time, managers may succumb to self-satisfaction, and if the context suddenly changes, their reaction is delayed, which is a pity. It is, therefore, no coincidence that in a graphical representation (Figure 2) of all five contexts, they are simple and chaotic. Delayed reactions can result in disaster. In order to identify changes in the context in a timely manner, it is important that management does not lose contact with its surroundings to avoid micro-management. It must work to create a communication channel that would ensure the need for early warning of the undesirable change. It should be remembered that the best experience is based on the experience of the past and it is very ineffective if people are prevented from abandoning the established processes if they stop working. 


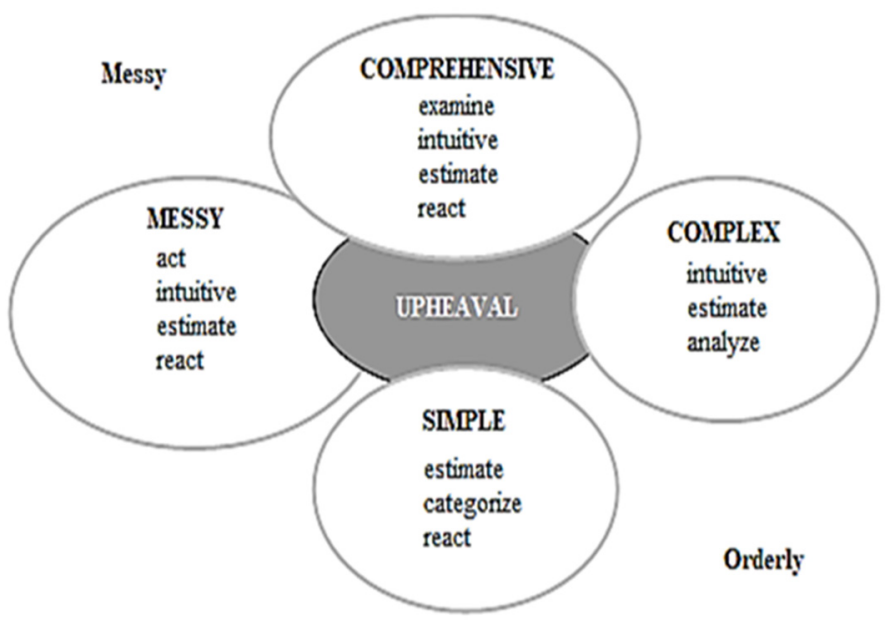

Figure 2. Cynefin framework [34].

\subsection{Complex Context}

In such contexts, there may be several correct responses to a particular stimulus, and although the cause-effect relationship is clear, not everyone will see it. It is an area of "known unknowns". Managers need not only identify (the incoming instalment is lower than it should have been), categorize (check the documentation and find out how to proceed with the next instalment), react appropriately (will not accept the payment), but especially:

- Evaluate intuitively.

- Analyze.

- React.

Such a procedure requires expertise (for example, a car driver may know that something is wrong with his car, because, for example, the engine is knocking, but only an expert-a mechanic — can diagnose the problem). Since there may be many good practices to deal with a problem within a complex context, these options need to be assessed, in which good practice is even more helpful than the best practice. An example is the design of a new mobile phone of which there may be more variants, all of which may be correct. As in the case of simple contexts, it is necessary to bear in mind the threat of so-called circular thinking, which tends to be practiced more by experts than by managers. Therefore, an unconventional solution that deviates from the routine framework, especially if a "non-expert" designs it, is often overlooked, which may later prove to be a mistake. In some crises, such "rebellious" solutions can be used with a greater effect than learned and proven. It follows that a flexible manager should hear not only the experts and their suggestions, but also the ideas of others. If a group of experts meet to solve a problem in complex contexts, it may happen that, at some point, the group is unable to move out of place and is unable to agree, for various reasons. This is another potential problem that we call analytical paralysis. In such a case, it sometimes helps to move into an unknown environment, which can be an inspiration for innovative thinking. Solving problem situations requires time and is always a compromise between finding an unconventional solution and a simple solution.

\subsection{Complex Context}

The complexity differs from the other contexts mentioned above in that the correct answer to the problem does not exist. It is an area of "unknown unknowns." This kind of context is so typical of today's business environment. The reason is that most situations are not routine, but are variable, which is also what allows decision-making processes to adapt. It is also very important that the reasons for the occurrence and course of a particular situation are often recognized only afterwards-retrospectively. Managers, therefore, cannot choose the procedure waiting to see the outcome. They must, therefore, probe, intuit, emotionally evaluate, and react. If managers do not believe in the correctness of this procedure or become impatient, they can slip to the level of traditional directive 
management, a serious problem in complex contexts. The effect of this management will not necessarily occur.

\subsection{Chaotic Context}

Finding the right answers, in this case, makes no sense, since the cause-and-effect relationships cannot be determined. They are constantly moving and there is no guaranteed procedure or solution formula. This is an area of unknown "unknowables". Managers have a single mission, to stop negative development, to "stop bleeding", not to look for a solution to the problem. This is not the case; in which case it is necessary to correct the problem itself. First, it is necessary to remove the mess and chaos and reveal the places that are stable and the places where there is no stability and then respond by trying to turn the chaotic situation into a complex one. The manager must manage as strictly as possible and communicate from top to bottom. In a chaotic environment, there is no time to ask for information or even to find out information. A flexible manager should be able to change the style of management and decision-making to suit changing circumstances and the current business environment. The appropriateness of choosing which style is very important. Therefore, in addition to flexibility, the manager must also estimate correctly in what context he is currently in. This is helped by certain warning signals and by the determination of tasks and responses to the warning signals, shown in Tables 1-4.

Table 1. Simple context.

\begin{tabular}{|c|c|c|c|c|}
\hline & Characteristics of Context & Task Manager & Warning Signals & $\begin{array}{c}\text { Responses to Warning } \\
\text { Signals }\end{array}$ \\
\hline Simple & $\begin{array}{c}\text { need for } \\
\text { professional diagnosis } \\
\text { cause and effect } \\
\text { relationships are possible } \\
\text { to guess, but not } \\
\text { always obvious } \\
\text { unknown unknown } \\
\text { fact-based management }\end{array}$ & $\begin{array}{l}\text { perceive intuitively } \\
\text { analyze and respond } \\
\text { create expert panels and } \\
\text { listen to } \\
\text { opposing counsel }\end{array}$ & $\begin{array}{l}\text { experts convinced of } \\
\text { their truth } \\
\text { analysis paralysis } \\
\text { panels of experts, } \\
\text { opinions of non-experts } \\
\text { are excluded }\end{array}$ & $\begin{array}{l}\text { to encourage rebuttal } \\
\text { using experiments to } \\
\text { eliminate } \\
\text { circular thinking }\end{array}$ \\
\hline
\end{tabular}

Table 2. Complex context.

\begin{tabular}{|c|c|c|c|c|}
\hline & Characteristics of Context & Task Manager & Warning Signals & $\begin{array}{c}\text { Responses to Warning } \\
\text { Signals }\end{array}$ \\
\hline Complex & $\begin{array}{l}\text { repetitive patterns } \\
\text { and outbreaks, } \\
\text { clear cause-and-effect } \\
\text { relationships, } \\
\text { the existence of the } \\
\text { correct answer } \\
\text { we know each other, } \\
\text { fact-based management }\end{array}$ & $\begin{array}{c}\text { perceive intuitively, } \\
\text { categorize, react, } \\
\text { ensure appropriate } \\
\text { processes, } \\
\text { delegate, } \\
\text { use best practice, } \\
\text { and communicate clearly }\end{array}$ & $\begin{array}{l}\text { complacency and } \\
\text { comfort, } \\
\text { efforts to simplify, } \\
\text { circular thinking, } \\
\text { and stability of old rules }\end{array}$ & $\begin{array}{l}\text { creating communication } \\
\text { channels, } \\
\text { connection with } \\
\text { micro-management, and } \\
\text { assume things are simple }\end{array}$ \\
\hline
\end{tabular}


Table 3. Complex context.

\begin{tabular}{|c|c|c|c|c|}
\hline & Characteristics of Context & Task Manager & Warning Signals & $\begin{array}{l}\text { Responses to Warning } \\
\text { Signals }\end{array}$ \\
\hline Complex & $\begin{array}{l}\text { constant change and } \\
\text { inability to predict, } \\
\text { there is no correct answer, } \\
\text { emergence of the solution, } \\
\text { unknown unknown, } \\
\text { a number of } \\
\text { competing ideas, } \\
\text { the need for a creative } \\
\text { approach, and } \\
\text { leadership is based on } \\
\text { formulas }\end{array}$ & $\begin{array}{c}\text { Probe, } \\
\text { perceive intuitively, } \\
\text { respond, } \\
\text { increase the level of } \\
\text { interaction and } \\
\text { communication, and the } \\
\text { use of methods leading } \\
\text { to the production of } \\
\text { new ideas }\end{array}$ & $\begin{array}{l}\text { the tendency to return to } \\
\text { the habitual directive } \\
\text { management style, } \\
\text { tendency to look for facts, } \\
\text { and trying to solve the } \\
\text { problem as quickly as } \\
\text { possible }\end{array}$ & $\begin{array}{l}\text { be patient and take time } \\
\text { to consider, } \\
\text { and use approaches to } \\
\text { encourage interaction }\end{array}$ \\
\hline
\end{tabular}

Table 4. Chaotic context.

\begin{tabular}{|c|c|c|c|c|}
\hline & Characteristics of Context & Task Manager & Warning Signals & $\begin{array}{c}\text { Responses to Warning } \\
\text { Signals }\end{array}$ \\
\hline Chaotic & $\begin{array}{l}\text { high degree of confusion, } \\
\text { no cause-effect } \\
\text { relationships exist, } \\
\text { the need to implement a } \\
\text { number of decisions in the } \\
\text { absence of time, } \\
\text { high voltage, and } \\
\text { leadership is based on } \\
\text { formulas }\end{array}$ & $\begin{array}{c}\text { act intuitively, perceive, } \\
\text { respond, } \\
\text { look for what works } \\
\text { rather than finding the } \\
\text { right answers, } \\
\text { take steps to restore } \\
\text { order, and } \\
\text { communicate clearly } \\
\text { and directly }\end{array}$ & $\begin{array}{l}\text { the use of directive } \\
\text { management methods } \\
\text { more than necessary, } \\
\text { personality cult, } \\
\text { missed opportunities for } \\
\text { innovation, and } \\
\text { unrelenting chaos }\end{array}$ & $\begin{array}{l}\text { mechanism setting } \\
\text { (parallel teams), } \\
\text { use the opportunities of a } \\
\text { chaotic environment to } \\
\text { your advantage, and } \\
\text { seek to turn chaos into a } \\
\text { complex context }\end{array}$ \\
\hline
\end{tabular}

\subsection{Knowledge Management, Its Importance and Use in the Company}

In a company in which knowledge is to become a decisive factor, a change in people's minds and a change in corporate culture, is essential. Not every company culture automatically enables knowledge exchange. To assess the state of affairs of this issue, it is appropriate to analyze the style of the company in terms of working atmosphere. Businesses with a more creative climate (where the work process is associated with confidence, acceptance of mistakes, meeting, teamwork, good communication, common language, risk appetite, acceptance of new ideas and ideas, the ability to listen and help, appreciation of knowledge, and initiative) have more favorable prerequisites for the exchange of knowledge than a less creative organization. This is characterized by a rather individualistic approach, a higher degree of avoidance of uncertainty, and a preference for established working practices and available knowledge. Such an atmosphere in the company is not suitable for the exchange of knowledge. Although this is a complex problem, solutions can be found to overcome the obstacles given by a less supportive culture. It is interesting to confront the whole spectrum of theoreticians' opinions on the importance of knowledge management with its practical use, not only in Slovakia but also in other countries. In [35], the authors claimed that despite the acknowledged importance of knowledge management (KM), many employees avoid practicing KM at the individual level. This avoidance often leads to a loss of intellectual capital due to employee turnover. Greater interest in the application of knowledge management can be seen across different sectors in different countries, as exemplified by the authors of [36]. They noted that knowledge management functions have developed to address the problems of low organizational commitment (higher turnover rates) and knowledge-workers' performance and, in the context of this fact, examined the mediation role of organizational commitment in the relationship between knowledge management practices and knowledge-worker performance. The use of knowledge in a company is not an end; there are several reasons for working with knowledge: 
- Businesses become "knowledge-sensitive", with knowledge becoming as important or more important than capital. This is because the market is becoming more complex and knowledge is becoming the only tool that allows it to be placed at a competitive edge, so it is important to manage that knowledge.

- Forgetting-the market is constantly changing; it is necessary to change the characteristics of the product and change the way it operates in the market; the company must be able to forget what is inappropriate now and focus on what the market requires. Knowledge enables an enterprise to be "at the forefront of change", enabling knowledge to survive and exploit external change (economic and political change). The market will, therefore, change, and knowledge will make it possible to take advantage of the newly created "opportunity window".

- What is above standard today may not be later (for example, e-mail). The market is complex, requiring the integration of several market segments, and the increasing complexity can be managed through knowledge.

- Knowledge makes better decisions.

- Knowledge sharing-it is good for an organization to distribute knowledge among people. Knowledge is mobile - the knowledge of the organization is located (among other things) in people, so knowledge can get away from day to day by leaving people with knowledge. The market is globalizing, so competition is increasing, so there is a need to find an advantage through knowledge.

Enterprises managing the knowledge management system can be divided into two basic types: Lower level—level 1: businesses need only manage their core activities. Higher level-level 2: In addition to first-level processes, a higher-level business also wants to manage above-standard knowledge, thereby gaining additional knowledge that gives it an added advantage over its competitors. The goal of any business should be to move to a higher level. Otherwise, it is in danger of extinction. The basic level of knowledge and knowledge management has only two out of four levels of knowledge in mainstream businesses: "know what" and "know how". An effective knowledge model also seeks to cover the "know why" area of knowledge, thus answering the questions of why the knowledge is important, not just how it should be used. The highest degree of application of knowledge in business is the "care why", answering the question of why and how to use that knowledge to support people's enthusiasm and their passion.

\section{Discussion}

Slovak companies have a goal to fulfil, which is to try to use and develop the knowledge of the employees and to try to manage the knowledge systematically. Of course, in each company this effort and the intensity of these processes are different. However, based on theoretical knowledge and personal experience, we can state that there is a shift in the field of knowledge management in Slovak companies compared to the past-Slovak companies are increasingly aware of the importance of knowledge management. To confirm these facts, we present two surveys; the first is current from 2020, and the second is from the past.

\subsection{Survey No. 1: Companies Want to Build and Maintain Employee Knowledge}

Slovak companies consider building and maintaining the knowledge of the changing workforce to be the topic of 2020; $78 \%$ of them stated this. That is according to a survey by a major company, Deloitte. Almost nine thousand companies were included in the study from 119 countries, including Slovakia.

Companies from other countries consider 'well-being' to be the most important topic in the field of human resources- $80 \%$ of them think so. They also consider belonging $(79 \%)$ and knowledge management (75\%) very important.

The survey also shows that more than $70 \%$ of the surveyed Slovak companies think that belonging, remuneration, and HR analytics are other key topics in the field of human 
resources. While technology allows everything to be individualized, people need to feel a sense of belonging to something bigger.

Companies also consider knowledge management to be an important topic (75\%), which is a very high and gratifying number that confirms our statement that companies in Slovakia are increasingly aware of the importance of knowledge management. Based on the results of the study, Deloitte advises companies to focus on three main areas. The first is the meaning of work, the second is the potential and the way to make the most of people's abilities, and the third is the perspective of changing perceptions of threats rather than opportunities to make better and faster decisions while maintaining the necessary transparency [37].

4.2. Survey No. 2: The Slovak Business Environment Is Not Fully Prepared for the Implementation of Knowledge Management

Surveys show the following barriers to the implementation of knowledge management. The research was focused on the use of knowledge management in selected companies in Slovakia. The research aimed to find out the degree of awareness in organizations about the use of knowledge, how they use it, and what their benefits for increasing competitiveness are. The research was carried out on a sample of selected organizations from various sectors (telecommunications services, postal services, logistics and forwarding services, industrial organizations, construction and agricultural enterprises, public administration institutions, universities, organizations in the field of financial and insurance activities, and wholesale and retail Figure 3 [38].

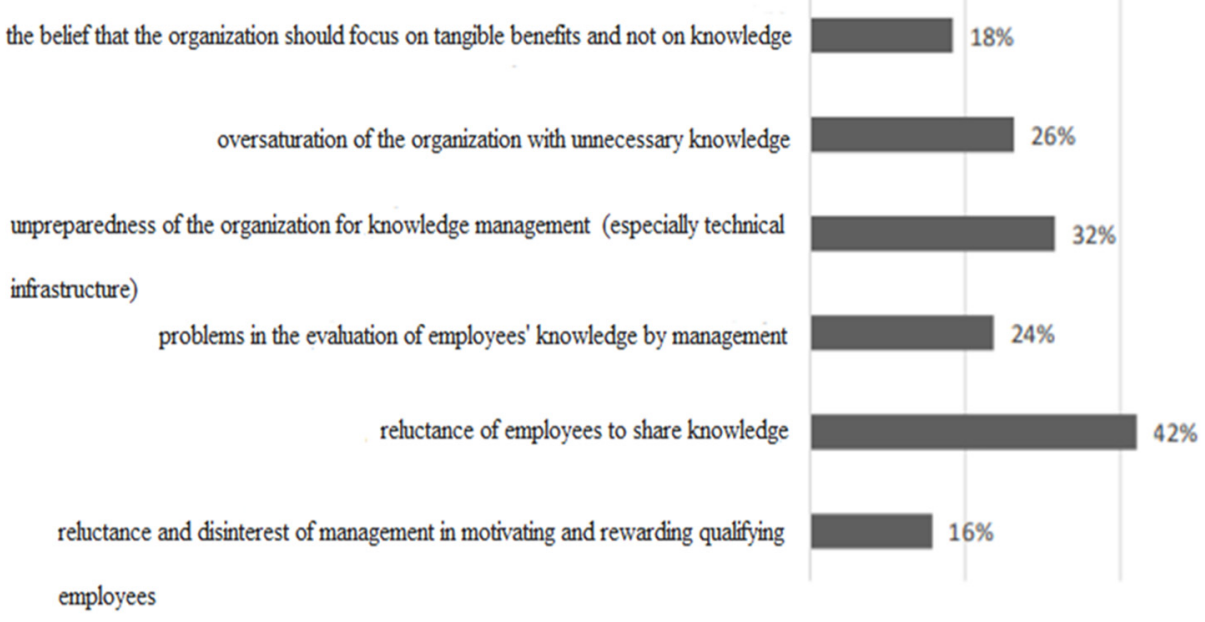

Figure 3. Obstacles to the implementation of knowledge management in Slovakia [38].

\subsection{Relationship of Knowledge Management to Decision-Making}

The relationship of knowledge management to decision-making is shown in Figure 4.

\subsection{Relationship of Knowledge Management (KM) to Decision-Making in Quality} Management (QM)

We have written about knowledge management in this paper. Now, we want to focus on quality and briefly define quality management, because a quality product is now considered a necessity and a matter of course in the hyper-competitive environment of today's market economy. In business, both national and international, increased emphasis is placed on meeting clearly defined standards in management systems as a guarantee of the quality of products and services provided. The quality management system, which is functional and efficient, ensures the performance of the implementation processes and allows the individual services provided by the company to be adapted precisely to the requirements and needs of a particular customer. 
Figure 5 is supplemented by Figure 3; it is a link between the field of knowledge management and decision-making in the field of quality management. The use of procedures and knowledge in the decision-making process was applied to quality management. The relationship of knowledge management to decision-making and to the decision-making process in quality management was included. In Table 5, we have shown and briefly described the basic, necessary, and follow-up steps and their logical sequence in the decision-making process that we apply in quality management to solve quality problems. Line 2 lists some of the important methods and tools that we use in each step of solving qualitative issues.

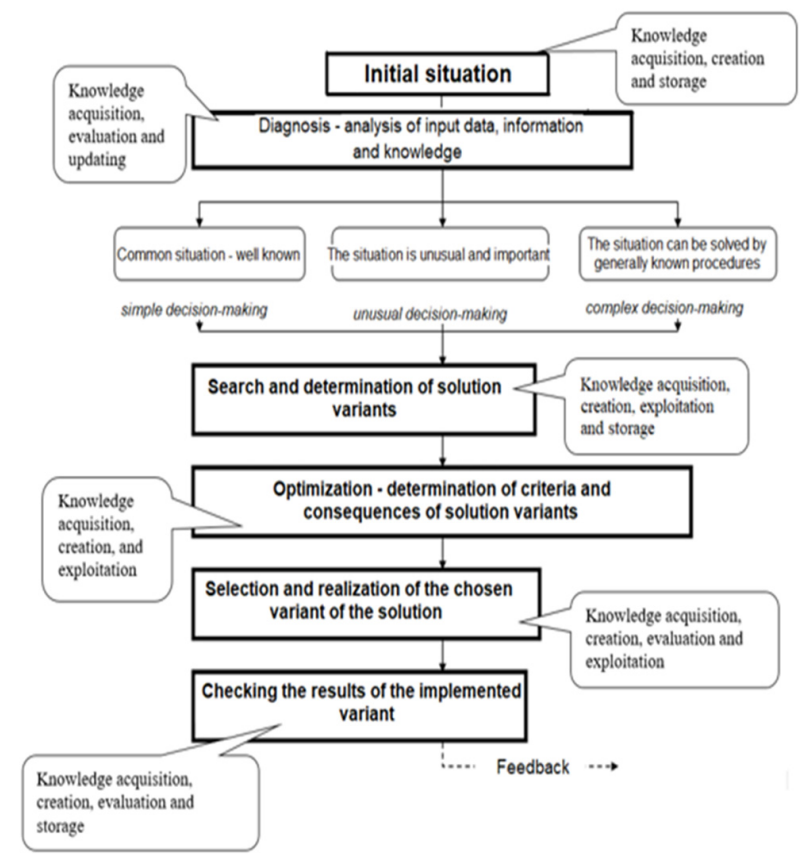

Figure 4. Knowledge management concerning decision-making [39].

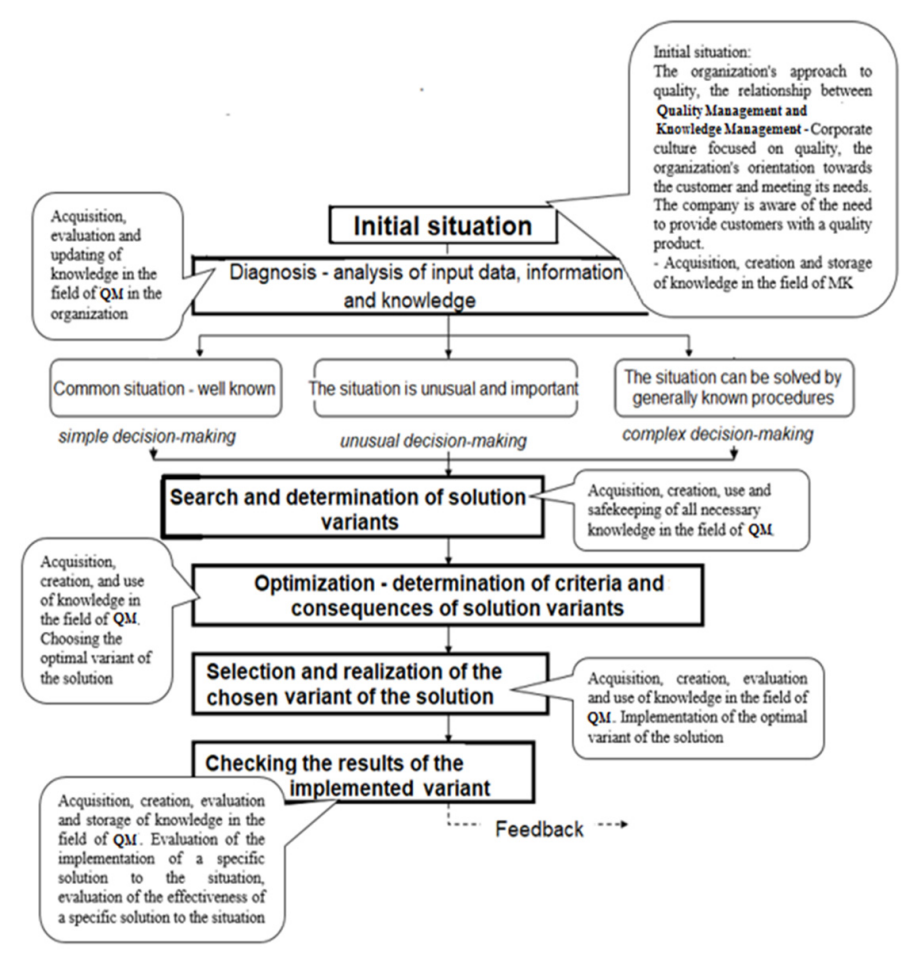

Figure 5. Knowledge management in relation to decision-making in quality management [40]. 
Table 5. Knowledge-management and the decision-making process in relation to quality management: Solving quality-related problems with quality management.

\begin{tabular}{|c|c|c|c|}
\hline & $\begin{array}{c}\text { Solution Quality Problems in } \\
\text { Enterprise (Product Quality and } \\
\text { Process Quality) }\end{array}$ & $\begin{array}{l}\text { Decision Assessment of Variable } \\
\text { Solution, Selecting the Best, Most } \\
\text { Effective Solution }\end{array}$ & Management Quality Improvement \\
\hline 1. & $\begin{array}{l}\text { Diagnosis of the problem and } \\
\text { diagnosis of the initial situation: } \\
\text { methods and tools }\end{array}$ & $\begin{array}{c}\text { Solution variants, analysis, } \\
\text { evaluation, choice of solution } \\
\text { variant, and solution procedure }\end{array}$ & $\begin{array}{l}\text { Quality improvement management, and } \\
\text { improving the quality of products } \\
\text { and processes }\end{array}$ \\
\hline 2. & $\begin{array}{l}\text { SWOT analysis, } \\
\text { statistical methods } \\
\text { systems engineering, } \\
\text { value analysis, } \\
\text { risk analysis, } \\
5 \times \text { why? etc. }\end{array}$ & $\begin{array}{l}\text { Knowledge support systems for MK, } \\
\text { generation and selection of ideas, } \\
\text { testing, simulation of solution } \\
\text { proposals, evaluation of proposals, } \\
\text { and implementation of proposals }\end{array}$ & $\begin{array}{l}\text { Quality improvement management, } \\
\text { training programs for employees, } \\
\text { improving the quality of products and } \\
\text { processes, quality improvement } \\
\text { methods: poka yoke, Kaizen Ideas, } \\
\text { management workshops, etc. }\end{array}$ \\
\hline
\end{tabular}

The description of the process of solving quality management problems in a company begins with a comprehensive, complete, and comprehensible description of a specific problem that needs to be solved; we are talking about the so-called problem diagnosis, which is the diagnosis of the starting situation. There are some suitable methods and tools for this. Then, the second step is the generation and selection of ideas and suggestions for problem-solving, followed by the analysis and evaluation of individual proposals and the selection of the optimal solution. This solution is supposed to eliminate the problem. The next step is the application of the chosen method for solving the problem in practice.

\section{Conclusions}

The current world community has a huge amount of data, information, and knowledge at its disposal, which is constantly growing, and knowledge is increasing in all disciplines until we get to the point that people sometimes have trouble understanding, sorting, and using them properly. If we ask ourselves, why this is, the answer is that it is the result of the main megatrends, which are globalization and the boom of technology (including information and communication technology). These megatrends resulted in a great expansion in human knowledge and in the application of this knowledge in practice. The intellectual capital of employees and its effective use in companies and organizations is one of the most important conditions of competitiveness, performance, and innovative skills of enterprises in the 21st century. Businesses must be aware of this, especially business managers, with which business management should identify and functionally implement knowledge management in their business environment. The acquisition, evaluation, use, and creation of new knowledge is becoming (and will continue to be) a significant and very important comparative advantage in the hyper-competitive environment of today's market economy. Acquisition, evaluation, use, and creation of new knowledge is needed in every single area of business management. This naturally also applies to the area of quality management in the company. Without sufficient knowledge in this field, you will not achieve the desired results. Quality management is a cross-sectional management system that affects every single area of business management. Therefore, managers need to use effective knowledge management in the decision-making process to improve this process. In this paper, we focused on these areas of business management and decision-making. Decision-making under conditions of uncertainty (in which the current global economy is located) places great demands on managers and business management. We also focused on the use of knowledge management concerning decision-making in quality management. We briefly described the relevant basic steps concerning decision-making and the decisionmaking process in quality management. We have assigned appropriate methods of quality management and quality improvement management to the individual basic steps in this process. We believe that the right link between governance, knowledge management, and 
decision-making will also contribute to sustainable development, a key requirement of the present.

Author Contributions: Conceptualization, O.P. and D.S.; methodology, O.P. and I.L.; software, O.P.; validation, O.P. and I.L.; formal analysis, O.P.; investigation, I.L.; resources, D.S. and J.S.; writingoriginal draft preparation, O.P. and J.M.; writing-review and editing, O.P. All authors have read and agreed to the published version of the manuscript.

Funding: The article was made with the support of grant project KEGA 011ŽU-4/2020 for the implementation of online education in the field of technology with an emphasis on the educational process for improving the skills and flexibility of engineering technology students.

Data Availability Statement: Not applicable.

Conflicts of Interest: The authors declare no conflict of interest.

\section{References}

1. Wennekers, S.; Thurik, R. Linking entrepreneurship and economic growth. Small Bus. Econ. 1999, 13, 27-56. [CrossRef]

2. Bosma, N.; Schutjens, V. Understanding regional variation in entrepreneurial activity and entrepreneurial attitude in Europe. Ann. Reg. Sci. 2011, 47, 711-742. [CrossRef]

3. Fritsch, M. Handbook of Research on Entrepreneurship and Regional Development: National and Regional Perspectives; Edward Elgar Publishing: Cheltenham, UK, 2013.

4. Gibb, A.; Haskins, G.; Robertson, I. Leading the entrepreneurial university: Meeting the entrepreneurial development needs of higher education institutions. In Universities in Change; Springer: New York, NY, USA, 2013; pp. 9-45.

5. Gulani, M.G.; Usman, A. Financing small and medium scale enterprises (SMEs): A challenge for entrepreneurial development in Gombe state. Asian J. Bus. Manag. Sci. 2012, 2, 17-23.

6. Buang, N.A.; Awalludin, D.E. Managing quality entrepreneurship course for community college students alaysia. Int. Bus. Manag. 2011, 5, 255-265.

7. Moftian, N.; Gheibi, Y.; Khara, R.; Safarpour, H.; Samad-Soltani, T.; Vakili, M.; Fooladlou, S. The effects of a spiral model knowledge-based conversion cycle on improving knowledge-based organisations performance. Int. J. Knowl. Manag. Stud. 2022, 13, 71-89. Available online: http:/ / emijournal.cz/wp-content/uploads/2020/08/MANAŽMENT-ZNALOSTÍ-A-TVORBAINOVÁCIÍ.pdf (accessed on 20 August 2021). [CrossRef]

8. Karaś, E.; Piasecka-Głuszak, A. Knowledge management-Why so important. In Management Sciences; Wrocław University of Economics: Wrocław, Poland, 2013; p. 4.

9. Wroblowska, Z. Personality requirements for Ukrainian and Czech managers creating brands as a competitive advanatage. J. Compet. 2019, 11, 152-167. [CrossRef]

10. Chorvátová, D. Implementácia znalostného manažmentu v organizácii; Ekonomická univerzita v Bratislave: Bratislava, Slovakia, 2011.

11. Katuščáková, M. Znalostný Manažment; Centrum vedecko-technických Informácií SR: Bratislava, Slovakia, 2009.

12. Younas, M.; Noor, A.S.M.; Arshad, M. Knowledge management framework for decision making in higher education institutions. Intell. Autom. Soft Comput. 2022, 31, 83-99. [CrossRef]

13. Abubakar, M.; Maher, H.E.; AlevElçia, A.A. Knowledge management, decision-making style, and organizational performance. J. Innov. Knowl. 2019, 4, 104-114. [CrossRef]

14. Raquel Ureña, R.; Chiclana, F.; Melançon, G.; Herrera-Viedma, E. A social network based approach for consensus achievement in multiperson decision making. Inf. Fusion 2019, 47, 72-87. [CrossRef]

15. Riplová, K.; Hrubizna, M. Příležitosti mladé generace v oblasti vědy, výzkumu a inovací; Strategické rozhodovanie a riadenie znalostí v podniku. In II. Mezinárodní Konference Studentské Vědecké a Odborné Činnosti, Kunovice, Evropský; Polytechnický Institut: Kunovice, Czech Republic, 2008.

16. Broggi, G. Decision Modeling in Policy Management: An Introduction to the Analytic Concepts; Kluwer Academic Publishers: Boston, MA, USA, 1999.

17. Klein, D. Decision-Analytic Intelligent Systems: Automated Explanation and Knowledge Acquisition; Lawrence Erlbaum Publishing: Mahwah, NJ, USA, 1994.

18. Thierauf, R. Creative Computer Software for Strategic Thinking and Decision Making: A Guide for Senior Management and MIS Professionals; Quorum Books: Westport, CT, USA, 1993.

19. Chako, G.K. Decision Making Under Uncertainty: An Applied Statistics Approach; Praeger: New York, NY, USA, 1990.

20. Brynjolfsson, E.; Hitt, M.L.; Heekyung, H.K. Strength in Numbers: How Does Data-Driven Decisionmaking Affect Firm Performance? 2011. Available online: http:/ / ssrn.com/abstract=1819486 (accessed on 17 January 2016).

21. Davenport, T.H. BI and organizational decisions. Int. J. Bus. Intell. Res. 2010, 1, 1-12. [CrossRef]

22. Majtán, M. Manažment, 2nd ed.; SPRINT: Bratislava, Slovakia, 2005.

23. What Is Quality-Business Excellence. Available online: http://www.bexcellence.org/What-Is-Quality.html (accessed on 17 January 2016). 
24. Crosby, P. Quality is Free; McGraw Hill: New York, NY, USA, 1979.

25. Dudzevičiute, G. Conceptual approaches towards sustainability. J. Secur. Sustain. 2012, 4, 261-272. [CrossRef]

26. Nenadál, J. Modern Quality Management; Management Press: Praha, Czech Republic, 2008.

27. Top 25 Quality Management Quotes IA-Z Quotes. Available online: https://www.azquotes.com/quotes/topics/qualitymanagement.html (accessed on 28 August 2021).

28. Sedlák, M. Manažment; Iura Edition: Bratislava, Slovakia, 2009; p. 434.

29. Majtán, M. Manažment; Sprint: Bratislava, Slovakia, 2007; p. 424.

30. Hangoni, T.; Imrichová, A. Manažment a Jeho Aplikácia v Sociálnej Práci; ELPIS: Gorlice, Poland, 2010; p. 136.

31. Donnelly, J.; Gibson, L.J.; Ivancevich, M.J. Fundamentals of Management; Irwin: Boston, MA, USA, 1992; p. 358.

32. Poniščiaková, O. Rozhodovanie po novom. J. ProIN 2013, 14, 14-16. Available online: https://www.mindtools.com/pages/ article/cynefin-framework.htm (accessed on 17 June 2020).

33. Shamim, S.; Cang, S.; Yu, H. Impact of knowledge oriented leadership on knowledge management behaviour through employee work attitudes. Int. J. Hum. Resour. Manag. 2019, 30, 2387-2417. [CrossRef]

34. Razzaq, S.; Shujahat, M.; Hussain, S.; Nawaz, F.; Wang, M.; Ali, M.; Tehseen, S. Knowledge management, organizational commitment and knowledge-worker performance: The neglected role of knowledge management in the public sector. Bus. Process. Manag. J. 2019, 25, 923-947. [CrossRef]

35. Survey: Slovak Companies Want to Build and Maintain Employee Knowledge. 2020. Available online: https://www2 deloitte.com/en/en/footerlinks/pressreleasespage/press-releases-archive/trendy-v-oblasti-udskych-zdrojov-ako-ich-vidiaslovenske-firmy-.html (accessed on 15 January 2021).

36. Stríček, I.; Štofková, K. New approaches to management in a dynamic business environment. Bus. Econ. Manag. $2013,3,36$.

37. Hrubizna, M. Rozhodovanie v znalostnom manažmente; Presentation; Žilinská univerzita v Žiline. Fakulta riadenia a informatiky: Žilina, Slovakia, 2019.

38. Hrubizna, M.; Litvaj, I. Rozhodovanie v znalostnom manažmente s ohl'adom na riadenie kvality; Presentation; Žilinská univerzita v Žiline, Fakulta riadenia a informatiky: Žilina, Slovakia, 2020.

39. Mikuš, P.; Droppa, M. Základy Manažmentu; Katolícka Univerzita v Ružomberku (VERBUM): Ružomberok, Slovakia, $2010 ;$ p. 261.

40. Manažérstvo Kvality. Available online: https://www.tuv-nord.com/sk/sk/systemy-manazerstva/manazerstvo-kvality/ (accessed on 17 June 2020). 